Irina Pospelova,

PhD (Candidate of Psychological Sciences), associate professor, Department of Theory and Methods of Practical Psychology,

Olena Kosianova,

PhD (Candidate of Psychological Sciences), lecturer of the Department of Theory and Methods of Practical Psychology,
The State institution "South Ukrainian National Pedagogical University named after K. D. Ushynsky", 26, Staroportofrankivska Str., Odessa, Ukraine

\title{
THE INFLUENCE OF SOCIAL AND PSYCHOLOGICAL ATTITUDES OF MODERN SPOUSES ON
} THEIR MARRIAGE SATISFACTION

The present study analyzes the problem of finding the relationship between the level of marriage satisfaction and the peculiarities of the social and psychological attitudes of modern spouses. The motivational orientation of modern spouses is analyzed. It has been shown that the highest level of marriage satisfaction is observed in "families with adolescents", the lowest level - in "mature families". The interpersonal dealings between the spouses are revealed and the most important factors that negatively affect the marriage are singled out, which include: lack of emotional support, inflated expectations of marriage, dissatisfaction with the character of the spouse. It is shown that the more similarity in relation to important areas of life and common motivational orientations and needs the spouses have, the more level of satisfaction with family life they obtain. The similarity of characters and the presence of similar values in spouses keep the family together. In contrast, the sharp divergence between the real character of the spouse and the expectations from $\mathrm{him} / \mathrm{her}$ is the most influential factor that determines low marriage satisfaction.

Keywords: marriage satisfaction; peculiarities of the social and psychological attitudes of modern spouses; motivational orientation; interpersonal dealings between the spouses; factors that negatively affect the marriage.

Подано до редакиії 16.01.2020

УДК: 159.923 .31

DOI: https://doi.org/10.24195/2414-4665-2020-1-2

Юрій Чебан,

аспірант кафедри теорії та методики практичної психології, Державний заклад «Південноукраїнський національний педагогічний університет імені К. Д. Ушинського», вул. Старопортофранківська, 26, м. Одеса, Украӥна

\section{О МЕТОДАХ ДОСЛІДЖЕННЯ ЕМОЦІЙНО-ВОЛЬОВОГО ПОТЕНЦАЛУ ВИСОКОКВАЛІФІКОВАНИХ СПОРТСМЕНІВ-ВЕСЛУВАЛЬНИКІВ}

У статті представлені результати теоретико-емпіричного дослідження проблеми діагностики рівня розвитку емоційно-вольового потенціалу висококваліфікованих спортсменів-веслувальників на байдарках $і$ каное. Актуальність досліджуваної теми визначається важливістю емочійно-вольової підготовки спортсменів для досягнення ними максимальних результатів у спортивних змагання. Необхідним компонентом такої підготовки є психологічна діагностика емоційно-вольового потенціалу. Мета статті - дослідити можливості психологічної діагности рівня розвитку емоційно-вольового потенціалу висококваліфікованих спортсменіввеслувальників. Для дослідження емоційно-вольового потенціалу пропонується використовувати чотири класи методик. Перший включає методики визначення значень наявного емочійно-вольової потенціалу на основі самооцінки та експертної оцінки і такі, щуо будуються на певних специфічних тестових випробуваннях для визначення даних його резерву. Другий зорієнтований на діагностику різних емоційних і вольових властивостей особистості, таких як емоиійність, емоиійна зрілість, тривожність, емоиійна стійкість, впевненість, наполегливість, самовладання тощьо. Третій - містить методики оцінки таких особистісних особливостей як мотивачія досягнення; рівень розвитку пізнавальних процесів, характерологічних рис, а також певних індивідуально-динамічних даних. Четвертий - засоби оцінки вмінь та навичок самобілізації в передстартовій ситуаціі та в процесі вирішення змагальної задачі. Результати апробації методик першого класу засвідчили, щзо дані, які отримані за допомогою експертного оиінювання емоційно-вольового потенціалу спортсменів, самооиінки власного потенціалу самими спортсменами та тестування емоційно-вольових можливостей під час виконан- 
ня фізичних вправ, відповідають об'єктивним досягненням веслувальників у спортивних змаганнях та їх спортивній кваліфікачії. Проте, в найбільше це стосується саме експертної оцінки.

Ключові слова: вольові якості, емочійні якості, висококваліфіковані спортсмени-веслувальники, спортивна діяльність, емоційно-вольовий потениіал.

\section{блеми \\ Вступ та сучасний стан досліджуваної про-}

Зростаюча складність діяльності вимагає від багатьох фахівців необхідного емоційно-вольового потенціалу (Deci, Ryan, 2008; Chebykin, 1989; Кузнєцов, 2012; Підбуцька, 2017; Максименко, 2013; Сетяєва, Фурсов, 2010; Фоменко, Полілуєва, 2017; Чебан, Чебикін, 2019; Чебикін, 1995; Чумаков, 2007 та ін.). Ця проблема є ще більш актуальною для представників професій, в яких постійно зустрічаються ознаки екстремальних ситуацій (Бочарова, Данилішина, 2010; Рубцов, Малих, 2008; Смирнов, 2007 та ін.). До цієї категорії фахівців відносяться і висококваліфіковані спортсмени, які стикаються зі значними психологічними напруженнями, виборюючи першість у відповідальних міжнародних змаганнях. На такому рівні змагань боротьба за перемоги ведеться фактично з однаковою фізичною підготовленістю спортсменів і вирішальним виступає факт наявності емоційновольового потенціалу (Jones, et al., 2017; Milavic, Padulo, Grgantov, 2019; Підбуцька, 2017; Чебан, Чебикін, 2019 та ін.). Також можна стверджувати, що емоційно-вольовий потенціал висококваліфікованих спортсменів, зокрема, веслувальників, має надзвичайне значення в таких умовах. Це залежить від багатьох об'єктивних і суб'єктивних чинників, зокрема, від індивідуально-психологічних особливостей спортсменів (Henriksen, Storm, Stambulova, 2019; Rogowska, 2020; Габелкова, 2010; Чебикін, 1995; Сопов, 2016; Воронова, 2017 та ін.). Саме тому для планування спортивної підготовки висококваліфікованих веслувальників потрібно знати відносно наявний їх емоційно-вольовий потенціал. Аналіз спеціальної літератури 3 цього питання показав, що досліджувалися різні аспекти розвитку вольових якостей спортсменів як окремо, так і в комплексі 3 іншими особливостями особистості. У той же час методи діагностики безпосередньо емоційно-вольового потенціалу висококваліфікованих спортсменів-веслувальників в недостатній мірі розкриваються в спеціальній літературі. У зв'язку з цим була поставлена мета статті - дослідити можливості психологічної діагности рівня розвитку емоційно-вольового потенціалу висококваліфікованих спортсменів-веслувальників.

\section{Завдання дослідження:}

1. Уточнити зміст, показники і ознаки емоційновольового потенціалу особистості. 2. Визначити комплекс методів психологічної діагностики рівня розвитку емоційно-вольового потенціалу висококваліфікованих спортсменів-веслувальників та його детермінант.

\section{Методи}

Для розв'язання поставлених завдань використано комплекс теоретичних та емпіричних методів: аналіз і узагальнення психологічної літератури, систематизація, теоретичне моделювання, анкетування, метод експертних оцінок, тестування.

\section{Результати}

Показано, що емоційно-вольовий потенціал відображає відносну міру можливостей даного процесу для успішного здійснення діяльності особистості при подолані значних перешкод на шляху досягнення мети. При цьому така його міра може відображатися в ознаках, які характеризують інтеграцію емоційних та вольових особливостей, що супроводжують реалізацію необхідних дій в складних умовах при досягненні мети діяльності. Відповідно, показниками ії виступатиме зінтегрований прояв різних емоцій та вольових якостей, що реалізуються в даному процесі на різних етапах дій, спрямованих на досягнення такої мети. Крім того, як показали попередні наші дослідження (Чебан, Чебикін, 2019), емоційно-вольовий потенціал має явні і приховані властивості.

Емоційно-вольовий потенціал також може суттєво детермінуватися певними особистісними особливостями. Саме тому, при його оцінці, необхідно підходити комплексно, враховуючи не тільки прямі показники емоційно-вольової сфери в конкретних умовах та результатах діяльності, а також особистісні особливості, що можуть його детермінувати.

До прямих показників слід віднести, перш за все, визначену оцінку зінтегрованих специфічних ознак емоцій та волі, що реалізуються в складних емоціогенних умовах діяльності. В даному випадку мова йде про діяльність спортсменів-веслувальників високого рівня на відповідальних міжнародних змаганнях. Тобто емоційно-вольовий потенціал спортсмена відображає його можливості, що спрямовані на високу мобілізацію зусиль з виконання необхідних дій при подоланні труднощів та перешкод в надзвичайно відповідальних змаганнях для досягнення суттєвого (переможного) результату.

До детермінант емоційно-вольового потенціалу спортсмена також не рідко відносять самі вольові якості, емоційну стійкість, працьовитість, систематичне самовдосконалення емоційно-вольових якостей особистістю, достатні психофізіологічні можливості організму для досягнення високих спортивних результатів (Чебан, Чебикін, 2019).

По теперішній час недостатньо опрацьовані методи оцінки емоційно-вольового потенціалу спортсменів-веслувальників. На нашу думку, він розкривається через особливості розвитку відповідних вольових, емоційних, мотиваційних, моральних, інтелектуальних, нейродинамічних особливостей спортсмена.

Виходячи з узагальнення чисельних даних, пізнання емоційно-вольового потенціалу можна здійснювати за допомогою різних методів. При цьому центральна увага повинна зосереджуватися на аналізі певних вольових зусиллях, розвитку рис особистості, нейродинамічних характеристик і особливостях поведінки в стресогенній ситуації, що у сукупності відбиває емоційно-вольовий потенціал спортсмена. 
Важливо, щоб такий підхід передбачав комплекс як експериментальних, так і екстенсивних методик. До останніх можна віднести декілька класів методик. Перший - спрямований на самооцінку наявного емоційно-вольового потенціалу спортсменів та експертну оцінку тренерів, що працюють 3 даними спортсменами. Експериментальною методикою, що долучається до цього класу є випробування в реальних та змодельованих умовах реалізації дій спортсмена. Вона, поперше, близька за своїм змістом до структури рухів спортсмена у відповідному виді спорту; по-друге, виконання цих вправ вимагає вольових зусиль для досягнення успіху. Умови проведення - спортсмени оцінюють рівень розвитку власного емоційновольового потенціалу після того як вони ознайомляться 3 його ознаками і критеріями для оцінювання. Для застосування методу експертних оцінок в якості експертів залучаються тренери з відповідного виду спорту. Для тестування спортсменів-веслувальників за допомогою фізичних вправ їм пропонується, наприклад, просуватися в човні проти вітру, або через бокові хвилі, чи з гідрогальмом, вантажем у човні тощо. Це виконується 3 фіксацією часу виконання завдання і за умов конкуренції з іншими спортсменами. Показником, який отримується завдяки методикам першого класу, $\epsilon$ наявний рівень емоційновольового потенціалу спортсменів-веслувальників.

Другий клас об'єднує методи оцінки безпосередньо вольових та емоційних якостей спортсменів, які лише побічно діагностують рівень емоційновольового потенціалу спортсменів-веслувальників. Умови проведення дослідження відповідні до інструкцій, які містяться в тих чи інших бланкових методиках, опитувальниках. Показниками тестування виступають: емоційність, емоційна зрілість, тривожність, емоційна стійкість, впевненість, самовладання, сміливість, витримка, енергійність, терплячість, цілеспрямованість тощо.

Третій клас - методики, що діагностують особистісні і типологічні особливості спортсменів. Ці особливості мають детермінуюче значення для функціонування емоційно-вольового потенціалу спортсмена. Умови проведення - визначаються змістом психодіагностичних методик, які використовуються, а саме: шкала самоконтролю Р. Баумейстера, методика вивчення часової перспективи Ф. Зімбардо, шкала ком- петентності у часі самоактуалізаційного тесту Е. Шострома, методика Т. Елерса для діагностики мотивації до уникнення невдач, методика Дембо́-Рубинште́йн для вивчення самооцінки емоційних станів тощо. Показниками тестування методиками третього класу є: мотивація досягнення, певні індивідуально-динамічні дані, особливості різних пізнавальних процесів, характерологічні якості тощо.

Четвертий клас методик спрямований на вивчення можливостей спортсменів-веслувальників узгоджувати фізичні, емоційні та раціональні компоненти бойового стану. Прикладами таких методів є ментальні вправи, аутогенне та ідеомоторне тренування тощо. Умови проведення - за допомогою письмового опитування у спортсменів з'ясовуються їх засоби самомобілізації, в якості яких можуть бути словесні формулювання: самонаказ, самопереконання, самопідбадьорення, самонавіювання; розумові образи: суворого авторитету, самоідентифікація з кумиром, самоідентифікація $з$ природною стихією, уявлення перемоги тощо. Також враховується роль підтримки з боку тренера, друзів, уболівальників, родичів тощо. Показники - наявні вміння та навички самомобілізації спортсменів-веслувальників в передстартовій підготовці та в процесі вирішення змагальної задачі.

Наведемо результати апробації методик віднесених до першого класу, а саме: самооцінки, експертної оцінки і спеціальних фізичних вправ для вивчення емоційно-вольового потенціалу висококваліфікованих спортсменів-веслувальників. Перед обстеженням досліджуваним та експертам надавалася інформація: «Емоційно-вольовий потенціал спортсмена відображає його можливості, що спрямовані на власну мобілізацію виконання необхідних дій в надзвичайно відповідальних змаганнях для досягнення значного (переможного) результату». Далі, учасникам дослідження пропонувалася інструкція: «Виходячи 3 результатів участі у відповідальних змаганнях за останні два роки, просимо прочитати нижче наведені твердження (див. лист відповідей) про спортсменів та обрати те, що в більшій мірі відноситься до Вас (до спортсмена якого Ви оцінюєте), позначивши « $\sqrt{ }$. Ваші дані не будуть оприлюднені, а лише використані для розробки рекомендацій до психологічної підготовки в тренувальному процесі».

\section{Лист відповідей:}

- спортсмен, який мобілізує свій емоційно-вольовий потенціал, що дозволяє йому у вирішальні моменти відповідальних змагань завжди досягати високого, переможного результату ( $\quad$ );

- спортсмен, який мобілізує свій емоційно-вольовий потенціал, що дозволяє йому у вирішальні моменти відповідальних змагань часто досягати високого, переможного результату ( );

- спортсмен, який мобілізує свій емоційно-вольовий потенціал, що дозволяє йому у вирішальні моменти відповідальних змагань періодично досягати високого, переможного результату ( );

- спортсмен, який мобілізує свій емоційно-вольовий потенціал, що дозволяє йому у вирішальні моменти відповідальних змагань інколи досягати високого, переможного результату ( );

- спортсмен, який мобілізує свій емоційно-вольовий потенціал, що дозволяє йому у вирішальні моменти відповідальних змагань поодиноко досягає високого, переможного результату ( ). 
За результатами обстеження визначають наявний рівень спроможності спортсмена самомобілізуватися для досягнення високого результату у відповідальних спортивних змаганнях. Цей рівень можливостей конкретно та прямо вказує на розвиток емоційновольового потенціалу спортсмена-веслувальника. Обробку отриманих даних здійснюють за шкалою від 1 до 5 балів.

Наступна методика будується на певних специфічних тестових випробуваннях з визначення емоційно-вольового резерву. Для вивчення останнього були використані фізичні вправи, що «навантажують» емоційні та вольові можливості спортсмена. Результат їх виконання теж може характеризувати рівень емоційно-вольового потенціалу досліджуваного. Зокрема для веслувальників застосовувалися вправи наближені до їх основної діяльності. Враховуючи на те, що вони можуть проявляти свої вольові можливості як під час загальної фізичної підготовки в тренажерному залі, так і під час веслування у байдарці чи каное, де їм пропонувалося два види фізичних тестів. Це проходження в байдарці чи каное дистанції 150 метрів і вправи зі штангою в спортивному залі. У випадку 3 веслуванням, на початку тренування в човні спортсмен йде максимально швидко 150 метрів. При цьому фіксується час проходження цієї дистанції. Потім він повністю виконує обсяг роботи на тренуванні. Після чого знову максимально швидко проходить дистанцію 150 метрів. Співвідношення часу витраченого на дистанції до і після тренування вказує на можливості спортсмена мобілізуватися, виявляючи при цьому емоційно-вольові властивості. Варіант проведення тестування в тренажерному залі: пропонується вправа жим штанги лежачи від грудей на лаві. Вага штанги 25 кілограм. Досліджуваний вижимає штангу максимальну кількість разів за 30 секунд. Фіксуємо частоту серцевих скорочень (ЧСС), кількість виконаних повторень зі штангою. Далі, після п'ятнадцяти секундного відпочинку спортсмену потрібно тримати той же темп, але вже 1 хвилину, потім 1,5 хвилини. По завершенню визначається самопочуття (методика САН) i ЧСС, що вказує на психофізіологічну ціну виконаного тесту.

Для апробації методик віднесених до першого класу були задіяні веслувальники Національної збірної команди у кількості 27 чоловік. Були досліджені наступні показники: самооцінка можливостей спортсменів до самомобілізації; експертна оцінка цих можливостей; рівень самомобілізації в реальних умовах реалізації дій спортсмена. Крім того, враховувалися дані щодо спортивних результатів досліджуваних за останні два роки, які були узагальнені і представлені за допомогою п'ятибальної шкали оцінок.

Дослідження самооцінки можливостей самомобілізації емоційно-вольового потенціалу спортсменіввеслувальників показало, що за п'ятибальною шкалою оцінок, де 5 балів - дуже високий рівень, а 1 бал дуже низький, середня оцінка складає 4,1 бали, $\sigma$ дорівнює 0,98. Щодо результатів експертного оцінювання можливостей спортсменів мобілізувати свій емоційно-вольовий потенціал, то середня оцінка складає 3,22 бали, $\sigma$ дорівнює 1,3. Вивчення можливостей самомобілізації в реальних умовах реалізації дій спортсменів-веслувальників засвідчило, що середня оцінка складає 3,3 бали, $\sigma$ дорівнює 1,4. Як ми бачимо вибірка, враховуючи на значення стандартного відхилення, достатньо однорідна за означеними показниками. Середні оцінки за експертною оцінкою і результатом виконання тестових фізичних завдань майже співпадає, відповідно: 3,22 і 3,3. Середня оцінка за самооцінку своїх можливостей щодо самомобілізації, порівняно з експертною оцінкою та фізичним тестом, є значно вищою (t кр. = 90; при p<0,01) і складає 4,1 бали. Зв'язки цих показників зі спортивною результативністю з'ясовувалися за допомогою обрахування коефіцієнта кореляції Спірмена. Результати подані в таблиці 1.

Таблиця 1

Зв'язки показників емоційно-вольового потенціалу зі спортивною результативністю спортсменіввеслувальників

\begin{tabular}{|l|c|}
\hline \multicolumn{1}{|c|}{ Показники } & Спортивна результативність \\
\hline Самооцінка & 0,21 \\
\hline Експертна оцінка & $0,39^{*}$ \\
\hline Фізичний тест & 0,35 \\
\hline
\end{tabular}

Примітка. «**»- значимість на рівні $P<0,05$

Дослідження зв'язку (див. табл. 1) показало, що експертна оцінка тренерів можливостей спортсменіввеслувальників до самомобілізації в умовах відповідальних міжнародних спортивних змагань є найбільш адекватною відносно реальних спортивних результатів досліджуваних.

\section{Висновки}

1. Емоційно-вольовий потенціал відображає відносну міру можливостей даного процесу для успішного здійснення діяльності особистості. При цьому така його міра може відображатися в ознаках, які ха- рактеризують інтеграцію емоційних та вольових особливостей, що супроводжують реалізацію тих чи інших дій в складних умовах при досягненні мети діяльності. Відповідно показникам іiі виступатиме прояв різних емоцій та вольових якостей, що реалізуються в даному процесі на різних етапах дій, спрямованих на досягнення такої мети.

2. Особистісні особливості впливають на розвиток і прояв емоційно-вольового потенціалу. Саме тому, при його оцінці, необхідно підходити комплексно, враховуючи не тільки його прямі показники емоцій- 
но-вольової сфери в конкретних умовах та результатах діяльності, а також особистісні особливості, що можуть його детермінувати.

3. Комплексний підхід до експериментальної оцінки емоційно-вольового потенціалу висококваліфікованих спортсменів-веслувальників може включати чотири класи методик. Перший: методики визначення значень наявного емоційно-вольового потенціалу на основі самооцінки та експертної оцінки, а також ті, що будуються на фізичних тестових випробуваннях $з$ визначення даних його резерву. Другий: ме-

\section{Література}

1. Бочарова С. П., Данилишина С. І. Особливості професійно-психологічної підготовки у системі навчання фахівців екстремальних професій. Проблеми екстремальної та кризової психологї. 2010. № 7. C. 63-69.

2. Воронова В. І. Психологія спорту. Київ: Олімпійська література, 2017. 272 с.

3. Габелкова О. Є. Особистісні особливості спортсменів, які впливають на досягнення високих командних результатів. Вісник Харківського національного університету: серія психологія. 2010. № 913. C. $12-14$.

4. Кузнєцов М. А. Вольова регуляції діяльності: основні закономірності, етапи і механізми. Вісник Харківського начіонального педагогічного університету імені Г.С. Сковороди. Психологія. 2012. № 43(1). C. $110-128$.

5. Підбуцька Н.В. Особливості вольової саморегуляції професійних баскетболістів. Вісник ХНПУ імені Г.С. Сковороди. Психологія. 2017. № 1 (57). C. $235-244$.

6. Психологічні чинники самодетермінації особистості в освітньому просторі: монографія / За ред. С.Д. Максименка. Кіровоград: Імекс-ЛТД, 2013. 400 с.

7. Рубцов В. В., Малых С. Б. Психология экстремальных ситуаций: 2-е изд., стер. Москва: Психологический ин-т РАО, 2008. 304 с.

8. Сетяева Н. Н., Фурсов А. В. Психическая саморегуляция в подготовке спортсменов высокой квалификации циклических видов спорта. Сургут: РИО СурГПУ, 2010. 203 с.

9. Смирнов Б. А., Долгополова Е. В. Психология деятельности в экстремальных ситуациях. Харьков: Изд-во Гуманитарный Центр, 2007. 276 с.

10. Сопов В. Ф. Структура и содержание психологического обеспечения подготовки высококвалифицированных спортсменов. Спортивный психолог. 2016. № 1 (40). С. 37-40.

11. Фоменко К. І., Полілуєва І. В. Характеристика діагностичного інструментарію для дослідження саморегуляції у спортивній діяльності. Вісник Харківського національного педагогічного університету імені Г. С. Сковороди. Психологія. 2017. Вип. 56. С. 242256.

12. Чебан Ю. В., Чебикін О. Я. Природа эмоционально-волевого потенциала спортсмена. Наука $i$ ocвima. 2019. № 1. С. 36-44.

13. Чебыкин А. Я. Проблема эмоциональной тодики, що фіксують різні емоційні та вольові властивості спортсмена, такі як емоційність, емоційну зрілість, тривожність, емоційну стійкість, впевненість, самовладання тощо. Третій: методики, що діагностують такі важливі особистісні особливості як мотивацію досягнення, певні індивідуально-динамічні дані, різні пізнавальні процеси та характерологічні якості тощо. Четвертий: засоби вивчення сформованості необхідних спортивних дій, потрібних для досягнення мети у відповідальних змаганнях.

устойчивости: монография. Одесса: Южноукр. пед. ун-т им. К. Д. Ушинского, 1995. 195 с.

14. Чумаков М. В. Эмоционально-волевая регуляция деятельности в социальном взаимодействии: дис. ... канд. психол. наук: 19.00.05, 19.00.01. Ярославский гос. ун-т им. П.Г. Демидова. Ярославль, 2007. $440 \mathrm{c}$.

15. Юдин Э. Г. Системный подход и принцип деятельности. Методологические проблемы современной науки. Москва: Наука, 1978. 392 с.

16. Chebykin A. The teacher and emotional regulation of schoolchildren learning-activity. Voprosy psikhologii. Issue: 6. 1989. P. 42-49.

17. Deci E., Ryan R. Self-determination theory: a macrotheory of human motivation, development, and health [Electronic resource] Canadian Psychology. 2008. Vol. 49. № 3. P. 182-185. URL: http://www.academia.edu/8247176/Self-Determination Theory_A_Macrotheory_of_Human_Motivation_Develop ment_and_Health.

18. Henriksen K., Storm L. K., Stambulova N., et al. Successful and Less Successful Interventions With Youth and Senior Athletes: Insights From Expert Sport Psychology Practitioners. Journal of clinical sport psychology. 2019, 1 (13), 72-94.

19. Jones G., Milligan J., Llewellyn D., Gledhill A., Johnson M. I., et al. Motivational orientation and risk taking in elite winter climbers. International journal of sport and exercise psychology. 2017, 1 (15), 25-40.

20. Lozhkin G., Predko S. Athlete's styles of behavior under conditions of risk. International journal of psychology, 2008, 3-4 (43), 150-150.

21. Milavic B., Padulo J., Grgantov Z., et al. Development and factorial validity of the Psychological Skills Inventory for Sports, Youth Version - Short Form: Assessment of the psychometric properties. Plos one. 2019, 8 (14). URL: https://journals.plos.org/plosone/article?id=10.1371/journ al.pone.0220930 (Date of application: 28.02.2020).

22. Rogowska A. M. Personality differences between academic team sport players and physical education undergraduate students. Physical education of students. 2020, 1 (24), 55-62.

\section{References}

1. Bocharova, S. P., \& Danilishina, S. I. (2010). Osoblivosti profesiino-psikhologichnoi pidgotovki $\mathrm{u}$ sistemi navchannia fakhivtsiv ekstremalnykh profesii [Features of professional and psychological training in the system of training specialists of extreme professions]. 
Problemi ekstremalnoi ta krizovoi psihologii - Problems of extreme and crisis psychology, 7, 63-69 [in Ukrainian].

2. Voronova, V. I. (2017). Psikhologiia sportu [Psychology of sport]. Kyiv: Olimpiiska literatura [in Ukrainian].

3. Gabelkova, O. Ye. (2010). Osobistisni osoblivosti sportsmeniv yaki vplivaiut na dosiagnennia visokikh komandnykh rezultativ [Personal characteristics of athletes that affect the achievement of high team results]. Visnik Harkivskogo nacionalnogo universitetu: seriya psihologiya - Bulletin of Kharkiv National University: psychology series, 913, 12-14 [in Ukrainian].

4. Kuznietsov, M. A. (2012). Voliova reguliatsii diialnosti: osnovni zakonomirnosti, etapi i mekhanizmi [Volitional regulation of activity: basic patterns, stages and mechanisms]. Visnik Kharkivskogo natsionalnogo pedagogichnogo universytetu imeni G. S. Skovorody. Psikhologiia - Bulletin of Kharkiv National Pedagogical University named after G. S. Skovorodi. Psychology, 43(1), 110-128 [in Ukrainian].

5. Pidbutska, N. V. (2017). Osoblivosti voliovoi samoreguliaysii profesiinykh basketbolistiv [Features of volitional self-regulation of professional basketball players]. Visnik HNPU imeni G. S. Skovorodi. PsikhologiiaBulletin of KhNPU named after G.S. Skovorodi. Psychology, I (57), 235-244 [in Ukrainian].

6. Maksimenko, S. D. (Eds.). (2013). Psikhologichni chynnyky samodeterminatsii osobistosti $v$ osvitnomu prostori [Psychological factors of selfdetermination of personality in education]. Kirovograd: Imeks-LTD [in Ukrainian].

7. Rubtsov, V. V., \& Malyh, S. B. (2008). Psihologiya ekstremalnyh situatsiy [Psychology of extreme situations]. (2d ed.). Moscow: Psychology Institute of Russian Academy of Education [in Russian].

8. Setyaeva, N. N., \& Fursov, A. V. (2010). Psihicheskaya samoregulyatsiya $v$ podgotovke sportsmenov vysokoy kvalifikatsii tsiklicheskih vidov sporta [Mental self-regulation in the training of highly skilled athletes in cyclic sports]. Surgut: Editorial and Publishing Department of Surgut State Pedagogical University [in Russian].

9. Smirnov, B. A., \& Dolgopolova, E. V. (2007). Psihologiya deyatelnosti $v$ ekstremalnyh situatsiyah [Psychology of activity in extreme situations]. Harkov: Publishing House "Humanitarian Center" [in Russian].

10. Sopov, V. F. (2016). Struktura i soderzhanie psihologicheskogo obespecheniya podgotovki vysokokvalifitsirovannyh sportsmenov [The structure and content of psychological support for the training of highly qualified athletes]. Sportivny psiholog - Sports psychologist, 1 (40), 37-40 [in Russian].

11. Fomenko, K. I., \& Poliluyeva, I. V. (2017). Kharakteristika diagnostichnogo instrumentariiu dlia doslidzhennia samoregulyatsii $\mathrm{u}$ sportivnii diialnosti [Characteristics of diagnostic tools for the study of selfregulation in sports]. Visnik Kharkivskogo natsionalnogo pedagogichnogo universitetu imeni G. S. Skovorodi. Psikhologiia - Bulletin of Kharkiv National Pedagogical University named after G. S. Skovoroda. Psychology, 56, 242-256 [in Ukrainian].

12. Cheban, Yu. V., \& Chebykin, O. Ya. (2019). Priroda emotsionalno-volevogo potentsiala sportsmena [The nature of the athlete's emotional-volitional potential]. Nauka i osvita - Science and Education, 1, 36-44 [in Russian].

13. Chebykin, A. Ya. (1995). Problema emotsionalnoy ustoychivosti [The problem of emotional stability]. Odessa: South Ukrainian National Pedagogical University named after K. D. Ushynsky [in Russian].

14. Chumakov, M. V. (2007). Emotsionalnovolevaya regulyatsiya deyatelnosti $\mathrm{v}$ sotsialnom vzaimodeystvii [Emotional-volitional regulation of activities in social interaction]. Extended abstract of candidate's thesis. Yaroslavl: Yaroslavl State University named after P. G. Demidov [in Russian].

15. Yudin, E. G. (1978). Sistemny podhod i printsip deyatelnosti. Metodologicheskie problemy sovremennoy nauki [Systematic approach and principle of operation. Methodological problems of modern science]. Moscow: Nauka [in Russian].

16. Chebykin, A. (1998). The teacher and emotional regulation of schoolchildren learning-activity. Voprosy psikhologii, 6, 42-49 [in English].

17. Deci, E., \& Ryan, R. (2008). Self-determination theory: a macrotheory of human motivation, development, and health. Retrieved from http://www.academia.edu/8247176/Self-Determination Theory A Macrotheory of Human_Motivation Develop ment_and_Health [in English].

18. Henriksen, K., Storm, L. K., \& Stambulova, N., et al. (2019). Successful and Less Successful Interventions With Youth and Senior Athletes: Insights From Expert Sport Psychology Practitioners. Journal of clinical sport psychology, 13 (1), 72-94 [in English].

19. Jones, G., Milligan, J., Llewellyn, D., Gledhill, A., \& Johnson, M. I., et al. (2017). Motivational orientation and risk taking in elite winter climbers. International journal of sport and exercise psychology, 15 (1), 25-40 [in English].

20. Lozhkin, G., \& Predko, S. (2008). Athlete's styles of behavior under conditions of risk. International journal of psychology, 43 (3-4), 150-150 [in English].

21. Milavic, B., Padulo, J., \& Grgantov, Z., et al. (2019). Development and factorial validity of the Psychological Skills Inventory for Sports, Youth VersionShort Form: Assessment of the psychometric properties. Retrieved

from https://journals.plos.org/plosone/article?id=10.1371/journ al.pone.0220930 [in English].

22. Rogowska, A. M. (2020). Personality differences between academic team sport players and physical education undergraduate students. Physical education of students, 24(1), 55-62 [in English]. 
Yurii Cheban,

PhD student,

Department of Theory and Methods of Practical Psychology,

The State institution "South Ukrainian National Pedagogical University named after K. D. Ushynsky", 26, Staroportofrankivska Str., Odessa, Ukraine

\section{RESEARCH METHODS OF EMOTIONAL AND VOLITIONAL POTENTIAL OF HIGHLY QUALIFIED ROWING ATHLETES}

The article presents the results of theoretical and empirical study of the issue of diagnosing the level of development of emotional and volitional potential of highly qualified rowing athletes in kayaking and canoeing. The relevance of the research topic is determined by the importance of emotional and volitional training of athletes to achieve maximum results in sports competitions. The psychological diagnosis of emotional and volitional potential is a necessary component of such training. The aim of the article is to explore the possibilities of psychological diagnosis of the development level of emotional and volitional potential of highly qualified rowing athletes. It is proposed to use four types of methods to study the emotional and volitional potential. The first one includes methods for determining the values of the available emotional and volitional potential on the basis of self-assessment and expert assessment and those which are based on certain specific test to determine the data of its reserve. The second one is focused on the diagnosis of various emotional and volitional personality traits such as emotionality, emotional maturity, anxiety, emotional stability, confidence, perseverance, self-control, etc. The third one includes methods of assessing such personal characteristics as achievement motivation; the level of development of cognitive processes, characterological features, as well as certain individual and dynamic data. The fourth one includes means of assessing the skills and abilities of self-stabilization in the prestarting situation and in the process of solving a competitive issue. The results of approbation the first type of methods showed that the data obtained through expert assessment of emotional and volitional potential of athletes, selfassessment of athletes`own potential and testing the emotional and volitional capabilities during physical exercises correspond to the objective achievements of rowers in sporting competitions and their sport qualifications. However, most of all it concerns the expert assessment.

Keywords: volitional qualities, emotional qualities, highly qualified rowing athletes, athletic activities, emotional and volitional potential.

Подано до редакиії 29.02.2020

УДК: $159.942: 159.925$

DOI: https://doi.org/10.24195/2414-4665-2020-1-3

Олексій Чебикін,

доктор психологічних наук, академік НАПН України,

Державний заклад «Південноукраӥнський національний педагогічний університет імені К. Д. Уиинського», вул. Старопортофранківська, 26, м. Одеса, Украӥна

\section{ЕМОЩЙНИЙ ІНТЕЛЕКТ, ЙОГО ПІЗНАВАЛЬНО-МИСЛЕННЕВІ ОЗНАКИ ТА ФУНКЩЇ}

В представленій статті зроблено спробу виділити пізнавально-мисленнєві ознаки емоційного інтелекту та їх функції в цььому прочесі. Показано, щчо значна частина фахівців, не зважаючи на декларативну відповідність изього феномену до сфери емоиій та інтелекту, аналізує в якості предмета його дослідження соиіальний інтелект та його комунікативні ознаки, емоційну зрілість та ї̈ складові, саморегуляцію, емпатію, експресивність емоцій та ін. Можна припустити, щуо в такому випадку ознаки емоційного інтелекту підміняються тими, які відносяться до предмету дослідження інших психологічних явищ. Також слід погодитися, щьо всі психічні явища тісно пов'язані між собою, тим більще, щзо емоції приречено зінтегровані фактично в кожний процес. Але коли ми обираємо предметом дослідження емоційний інтелект, то природньо мова повинна йти про ті його ознаки, які в більщій мірі повинні відображати певні специфічні особливості емоцій в інтелекті. Запропоновано розглядати емоційний інтелект як психологічну властивість особистості, щуо характеризується проявом складних немов зінтегрованих, емоційно-пізнавальних та мисленнєвих особливостей, завдяки яким 